DOI: $10.21802 / \operatorname{artm} .2019 .2 .10 .98$.

УДК 616-002-008.953-092

\title{
СКЛАД ЛЕЙКОЦИТІВ ПЕРИФЕРИЧНОЇ КРОВІ: ІМУННІ ВЛАСТИВОСТІ ЛІМФОЦИТІВ У ЖІНОК З ОЖИРІННЯМ, ЯКІ ХВОРІ НА ІНСУЛІНОЗАЛЕЖНИЙ (НЕЗАЛЕЖНИЙ) ЦУКРОВИЙ ДІАБЕТ ДРУГОГО ТИПУ
}

\author{
Р.О. Сабадишин, О.П. Мялюк, О.В. Штрімайтіс, О.В. Садовник
}

Комунальний заклад вищої освіти «Рівненська медична академія» Рівненської обласної ради, кафедра хіміко-фармачевтичних дисииплін, м. Рівне, Україна,

ORCID ID: 0000-0002-9754-8667,

ORCID ID: 0000-0002-5090-6607,

ORCID ID: 0000-0002-1305-2251,

ORCID ID: 0000-0001-7391-2316,

e-mail: oksankamp@ukr.net

Резюме. На нашій планеті кожну двадцять першу секунду з'являється новий пацієнт, що страждає на цукровий діабет. Основну частину цих пацієнтів складають хворі на цукровий діабет (Цд) 2 типу. Число осіб 3 цим діагнозом, які потребують лікування інсуліном, неухильно зростає і вже давно перевищило кількість хворих на ЦД типу 1. У теперішній час близько $30 \%$ всіх хворих ЦД типу 2 отримують інсулін. Тривалість періоду від дебюту захворювання до початку інсулінотерапії сильно варіює і залежить від ряду факторів. Наприклад, зниження функціональних можливостей і розвиток відносної інсулінопенії або ж потреба в інсуліні може бути спровокована інсулінорезистентністю, внаслідок приєднання інтеркурентних захворювань, вагітності, ожиріння і т. д.

Для дослідження було обстежено 30 жінок з ЦД 2-го типу у віці від 30 до 50 років, які були розділені на дві групи: перша - 3 нормальною масою тіла і друга - 3 ожирінням. Хворих жінок з ожирінням розділили на дві групи, які є інсулінозалежними (незалежними). Контрольна група складала 30 здорових жінок такого ж віку, які були також розділені на дві групи: 3 нормальним IMT (<25 кг / м2) і з IMT > 29,9 кг / м2. Встановлено, що при ожирінні у всіх групах спостерігається статистично достовірний лейкоцитоз за рахунок моноцитозу і нейтрофільозу. Згідно з нашими даними інсулінозалежні жінки мали більш високу імунну реакцію організму за рахунок підвищення лімфоцитів. При використанні інсуліну в лікуванні Цд 2-го типу знизилась кількість нейтрофілів і моноцитів, що говорить про зменшення запальної реакції організму в інсулінозалежних пацієнтів. За результатами дослідження, ефективність використання інсуліну обумовлює більш високу протизапальну дію, ніж вживання пероральних цукрознижувальних засобів.

Ключові слова: лейкоцити, цукровий діабет другого типу, ожиріння.

Вступ. За даними Міжнародної федерації діабету (IDF), в цей час на цукровий діабет хворіють понад 246 млн. осіб. Було встановлено, що кожну 21-у секунду на нашій планеті з'являється новий пацієнт, що страждає на це захворювання. Основну частину цих пацієнтів складають хворі на цукровий діабет (ЦД) 2 типу. Число осіб з цим діагнозом, які потребують лікування інсуліном, неухильно зростає i вже давно перевищило кількість хворих на ЦД типу 1. У теперішній час близько $30 \%$ всіх хворих ЦД типу 2 отримують інсулін. У 1999 році ВООЗ виключила 3 нової класифікації цукрового діабету терміни інсулінозалежний i інсулінонезалежний цукровий діабет, залишивши тільки ЦД типу 1 і 2, це підкреслило той факт, що необхідність в інсулінотерапії не $\epsilon$ виключною характеристикою ЦД типу 1, але може визначатися цілим рядом причин і при ЦД типу 2. Тривалість періоду від дебюту захворювання до початку інсулінотерапії сильно варіює і залежить від ряду факторів. Найбільш значимий серед них - зниження функціональних можливостей і розвиток відносної інсулінопенії. В інших випадках потреба в інсуліні може бути спровокована інсулінорезистентністю, внаслідок приєднання інтеркурентних захворювань, вагітності, ожиріння і т. д. [1].

Обгрунтування дослідження. Особлива увага вчених, які займаються вивченням ЦД 2-го типу, прикута до наявності у людини надлишкової маси тіла або ожиріння, адже нині воно також розглядається як один з видів запалення. Нещодавно патологами при дослідженні підшлункової залози людини було виявлено, що у хворих на ЦД 2-го типу спостерігається виражене запалення переважно в панкреатичних острівцях Лангерганса [2].

Інформація про роль імунної системи в патогенезі ЦД 2-го типу, який супроводжується надлишковою масою тіла або ожирінням, незначна і неоднозначна. Існує думка, що зміни деяких показників природного і адаптивного імунітету у хворих на ЦД 2-го типу 3 надмірною масою тіла обумовлені не настільки самим захворюванням на цукровий діабет, скільки поєднаним ожирінням, так як в цей час встановлено, що жирова тканина (ЖТ) є потужним секреторним органом, який продукує адипокіни (лептин, адипонектин i ін.), які відіграють ключову роль в різних імунних реакціях. Разом з тим відомо, що рі- 
вень головних адипокінів, що регулюють ЖТ, в периферичній крові (ПК) людини визначають з урахуванням статевого диморфізму, тобто більш висока їх концентрація у жінок, ніж у чоловіків. У той же час наявні дослідження, присвячені з'ясуванню ролі ожиріння при ЩД 2-го типу, поодинокі, суперечливі i виконані переважно на обох статях [3].

Метою нашої роботи було з'ясувати зміни ряду показників імунітету (лейкоцитарний склад та імунні властивості лімфоцитів крові) при інсулінозалежному (незалежному) ЦД 2-го типу у жінок з ожирінням, зважаючи на значні статеві відмінності в секреції ряду адипокінів, що беруть участь в контролі функції імунної системи.

Матеріали та методи дослідження. Для дослідження обстежено 30 жінок ендокринологічного відділення К3 «Рівненський обласний спеціалізований диспансер радіаційного захисту населення Рівненської обласної ради» з ЦД 2-го типу у віці від 30 до 50 років, які були розділені на дві групи: перша -3 нормальною масою тіла (індекс маси тіла (IMT) $<25$ кг / м2) і друга - 3 ожирінням (IMT > 30 кг / м2). Крім того, хворих жінок, які мають ожиріння, було розділено на дві підгрупи, які $є$ інсулінонезалежними і тих, які приймають інсулінотерапію. Контрольна група складала 30 відносно здорових жінок такого ж віку, які були також розділені на дві групи: 3 нормальним IMT $(<25$ кг / м2) і 3 ожирінням - з IMT > 29,9 кг / м2. При антропометричному дослідженні у пацієнток визначали ріст і масу тіла 3 подальшим обчисленням IMT шляхом ділення маси тіла в кг на квадрат росту в метрах. При IMT нижче 18,5 кг / м2 вважали, що у пацієнтки недостатність ЖТ, при IMT між 18,5 і 24,9 кг / м2 - нормальна вага, від 25,9 до 29,9 кг / м2 надлишкова вага, при 30,0-35,0 кг / м2 - ознака ожиріння, а ще при більш високих показниках (> 35,0 кг / м2) - патологічне ожиріння. Зазначимо, що в анамнезі досліджуваних пацієнтів було виключено хронічні інфекції, атеросклероз, ХНН і ін., що сприяють лейкоцитозу. Загальну кількість лейкоцитів в ПК підраховували за допомогою гематологічного аналізатора у К3 «Пологовий будинок Рівненської міської ради». Лейкоцитарну формулу вивчали в мазках ПК на 200 клітин, забарвлених за Романовським-Гімзе. Вміст лімфоцитів визначали методом проточної цитометрії з використанням лазерного цитофлуориметpa BD FACSVerse фірми Becton Dickenson (США) у Рівненському обласному центрі громадського здоров`я. Мононуклеари виділяли 3 гепаринізованої ПК методом диференціального центрифугування в градієнті щільності фікол-уротраста 3 подальшим їх інкубуванням в пластикових чашках в CO2-інкубаторі протягом 1 год для усунення моноцитів. Поверхневі антигени лімфоцитів проти мембранних антигенів: CD3+, CD4+, CD8+, CD20+ i CD56+ - відмічали моноклональними антитілами, промаркованими флуо- ресцеїн-ізотіоціанатом або фікоеритрином фірм Becton Dickenson (США), Dako Cytomation (Данія).

Статистична обробка отриманих результатів досліджень проводилась 3 використанням загальноприйнятих методів варіаційної статистики за допомогою пакета статистичних програм Excel 2002 та Statistika for Windows (Statsoft Ins, США). Рівень вірогідності визначали за критерієм Стьюдента [4].

Результати дослідження. Нами встановлено, що при надмірній масі тіла, як у практично здорових жінок, так і у жінок, хворих на ЦД 2-го типу, спостерігається статистично достовірна зміна загальної кількості лейкоцитів, лейкоцитарного складу і деяких видів лімфоцитів ПК. Так, при порівнянні середніх даних, отриманих при гематологічному обстеженні жінок 3 нормальним IMT і з ожирінням, хворих на ЦД 2-го типу, було виявлено, що підвищення загальної кількості лейкоцитів в ПК пацієнтів 3 високим IMT більш значна, ніж у хворих 3 нормальним IMT, тобто $29,7 \%$ проти $8 \%(\mathrm{p}<0,05)$. Крім того, у хворих жінок 3 ожирінням, які перебувають на інсулінозалежній терапії, загальна кількість лейкоцитів значно підвищена за рахунок лімфоцитів і $є$ на $10 \%(\mathrm{p}<0,05)$ вищою щодо жінок з ЦД 2-го типу з ожирінням, але інсулінонезалежних. Найвищий лейкоцитоз спостерігався саме у інсулінозалежних пацієнток 3 ожирінням, тобто в середньому досягав 8,35×10 9/л (Рис.1., таб.1.).

У ході дослідження була виявлена у групі здорових і хворих жінок з нормальною масою тіла (IMT<25кг/м2) абсолютна кількість сегментоядерних нейтрофілів в ПК у пацієнтів з ЦД 2-го типу, по відношенню до таких у здорових жінок спостерігалось збільшення в середньому на 29,8\%, а у жінок з ожирінням таке співвідношення становило 50,2\% $(\mathrm{p}<0,05)$. Абсолютна кількість моноцитів в ПК у двох групах обстежуваних була ще більш високою, відповідно в середньому на $56,5 \%(\mathrm{p}<0,05)$ у худих і на $73,9 \%$ у жінок з ожирінням $(\mathrm{p}<0,05)$. Особливо значні зміни спостерігалися з боку кількості моноцитів - у вигляді моноцитозу.

Важливим виявилося визначення сегментоядерних нейтрофілів у хворих жінок з ожирінням при фармакотерапії інсуліном, яке показало зниження їх кількості на $12,7 \%(\mathrm{p}<0,05)$ у інсулінозалежних жінок порівняно з інсулінонезалежними хворими пацієнтами, визначення моноцитів теж показало зниження їх кількості на 6,2\% порівняно 3 наявністю моноцитів у ПК інсулінонезалежних пацієнтів. Цікавим виявилось статистично достовірне зростання лімфоцитів у хворих жінок 3 ожирінням на інсуліновій терапії на $11,3 \% \quad(p<0,05)$ порівняно 3 інсулінонезалежними пацієнтами, це пояснює позитивний вплив інсулінотерапії на імунні властивості організму і зниження запалення для хворих жінок на ЦД 2-го типу (Рис.2). 
Таблиця 1.

Загальна кількість лейкоцитів, лейкоцитарний склад і лімфоцити ПК здорових жінок 3 IMT $<25$ кг / м2 і з ожирінням, хворих на ЦД 2-го типу з IMT < 25 кг / м2, і жінок 3 ожирінням (IMT> 29,9 кг / м2), i хворих жінок на ЦД 2-го типу з ожирінням на інсулінозалежній і інсулінонезалежній фармакотерапії

\begin{tabular}{|c|c|c|c|c|c|c|}
\hline Клітини & $\begin{array}{l}\text { Здорові } \\
\text { жінки } \\
\text { нормаль- } \\
\text { ною масою } \\
\text { тіла, абсо- } \\
\begin{array}{l}\text { лютна кі- } \\
\text { лькість }\end{array}\end{array}$ & $\begin{array}{l}\text { Хворі жінки } \\
3 \text { нормаль- } \\
\text { ною масою } \\
\text { тіла, абсолю- } \\
\text { тна кількість }\end{array}$ & $\begin{array}{l}\text { Здорові } \\
\text { жінки } \\
\text { ожирін- } \\
\text { ням, абсо- } \\
\text { лютна } \\
\text { кількість }\end{array}$ & $\begin{array}{l}\text { Хворі жінки } \\
\text { з ожирінням, } \\
\text { абсолютна } \\
\text { кількість }\end{array}$ & $\begin{array}{l}\text { Хворі жін- } \\
\text { ки } 3 \text { ожи- } \\
\text { рінням, } \\
\text { інсуліноне- } \\
\text { залежні, } \\
\text { абсолютна } \\
\text { кількість }\end{array}$ & $\begin{array}{l}\text { Хворі жінки } \\
3 \text { ожирінням, } \\
\text { інсуліноза- } \\
\text { лежні, абсо- } \\
\text { лютна кіль- } \\
\text { кість }\end{array}$ \\
\hline Лейкоцити & $5,00 \pm 0,22$ & $5,40 \pm 0,22 *$ & $6,10 \pm 0,22$ & $7,91 \pm 0,25^{*}$ & $7,60 \pm 0,22$ & $8,35 \pm 0,26^{*}$ \\
\hline $\begin{array}{l}\text { Сегментояде- } \\
\text { рні нейтрофі- } \\
\text { ли }\end{array}$ & $2,85 \pm 0,21$ & $3,70 \pm 0,23 *$ & $3,25 \pm 0,23$ & $4,88 \pm 0,23^{*}$ & $4,58 \pm 0,22$ & $4,00 \pm 0,23^{*}$ \\
\hline $\begin{array}{l}\text { Паличкоядер- } \\
\text { ні нейтрофіли }\end{array}$ & $0,12 \pm 0,02$ & $0,17 \pm 0,03$ & $0,14 \pm 0,01$ & $0,22 \pm 0,03 *$ & $0,22 \pm 0,03$ & $0,19 \pm 0,03 *$ \\
\hline $\begin{array}{l}\text { Базофільні } \\
\text { нейтрофіли }\end{array}$ & $0,01 \pm 0,001$ & $0,02 \pm 0,01$ & $0,02 \pm 0,001$ & $0,04 \pm 0,01$ & $0,04 \pm 0,02$ & $0,04 \pm 0,02$ \\
\hline $\begin{array}{l}\text { Еозинофільні } \\
\text { нейтрофіли }\end{array}$ & $0,13 \pm 0,02$ & $0,05 \pm 0,02 *$ & $0,14 \pm 0,02$ & $0,10 \pm 0,02$ & $0,13 \pm 0,02$ & $0,12 \pm 0,02$ \\
\hline Моноцити & $0,23 \pm 0,02$ & $0,36 \pm 0,04^{*}$ & $0,46 \pm 0,05$ & $0,80 \pm 0,06^{*}$ & $0,87 \pm 0,05$ & $0,819 \pm 0,05^{*}$ \\
\hline Лімфоцити & $1,70 \pm 0,16$ & $1,68 \pm 0,14$ & $1,69 \pm 0,13$ & $2,12 \pm 0,20$ & $2,12 \pm 0,21$ & $2,36 \pm 0,21^{*}$ \\
\hline $\begin{array}{l}\text { CD3+- } \\
\text { лімфоцити }\end{array}$ & $0,82 \pm 0,1$ & $0,87 \pm 0,07$ & $0,90 \pm 0,12$ & $1,20 \pm 0,12^{*}$ & $1,19 \pm 0,12$ & $1,39 \pm 0,12^{*}$ \\
\hline $\begin{array}{l}\text { CD4+- } \\
\text { лімфоцити }\end{array}$ & $0,49 \pm 0,06$ & $0,56 \pm 0,05$ & $0,63 \pm 0,05$ & $0,92 \pm 0,08^{*}$ & $0,90 \pm 0,09$ & $1,09 \pm 0,09^{*}$ \\
\hline $\begin{array}{l}\text { CD8+- } \\
\text { лімфоцити }\end{array}$ & $0,34 \pm 0,04$ & $0,40 \pm 0,03$ & $0,37 \pm 0,05$ & $0,52 \pm 0,05^{*}$ & $0,50 \pm 0,05$ & $0,65 \pm 0,05^{*}$ \\
\hline $\begin{array}{l}\text { CD20+- } \\
\text { лімфоцити }\end{array}$ & $0,13 \pm 0,02$ & $0,16 \pm 0,02$ & $0,16 \pm 0,02$ & $0,22 \pm 0,03$ & $0,22 \pm 0,03$ & $0,27 \pm 0,03$ \\
\hline $\begin{array}{l}\text { CD56+- } \\
\text { лімфоцити }\end{array}$ & $0,13 \pm 0,01$ & $0,16 \pm 0,02$ & $0,14 \pm 0,02$ & $0,23 \pm 0,03^{*}$ & $0,20 \pm 0,03$ & $0,30 \pm 0,03^{*}$ \\
\hline
\end{tabular}

Примітка: * ${ }^{*}$ p $<0,05$ - відношення худих здорових жінок до худих хворих на ЦД 2-го типу, повних здорових жінок до хворих на ЦД 2-го типу з ожирінням і хворих жінок з ожирінням на інсулінонезалежній терапії до хворих жінок з ожирінням інсулінозалежних.
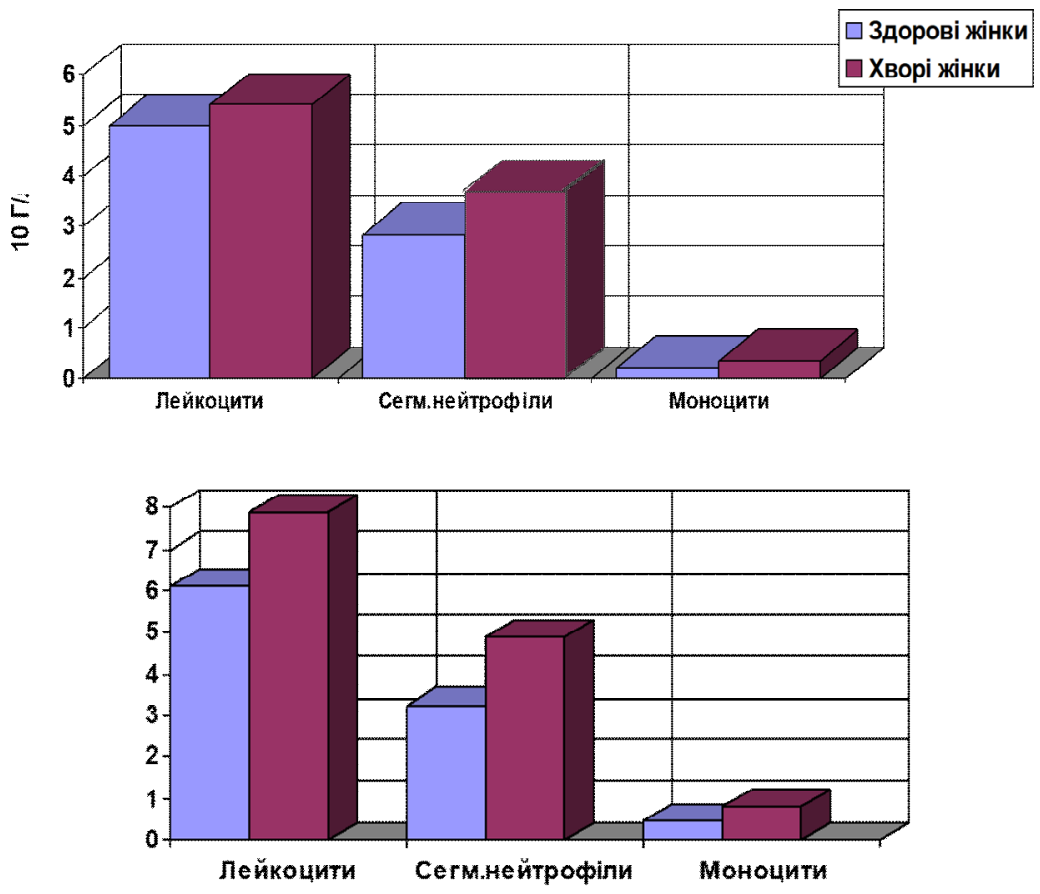

Рисунок 1. Загальна кількість лейкоцитів,

абсолютне число нейтрофілів і моноцитів в ПК:

А) у здорових осіб нормальної маси тіла і у хворих на ЦД 2-го типу жінок без ожиріння;

Б) у здорових осіб 3 надлишковою вагою i хворих на ЦД2-го типу жінок 3 ожирінням. 
При цитологічному дослідженні моноцитів у мазках ПК ці клітини у таких хворих виглядали збільшеними у розмірі та вміщали більшу кількість вакуолей, що свідчить про акумуляцію в цих клітинах ліпопротеїнів. Як наслідок, перевантаження клітин 3 кінцевим перетворенням їх в пінисті клітини і загибель, що збігається 3 дослідженнями моноцитів іншими вченими. Відомо, що нейтрофіли, 3 одного боку, завдяки фагоцитозу є головними захисниками організму від патогенів, а 3 іншого боку, при зміні імунологічної толерантності можуть брати участь в деструкції і дисфункції бета-клітин шляхом апоптозу [5]. Моноцити у великій кількості мігрують і заселя- ють ЖТ при ожирінні, є головними клітинами, секретуючими цілий спектр прозапальних і антизапальних цитокінів та хемокінів з адипоцитами, в тому числі інтерлейкін-1 $\beta$, -6 і фактор некрозу пухлини $\alpha$ в ЖТ, утворюючи функціональні комплекси, i, таким чином, відіграють кардинальну роль в патогенезі як Цд 2-го типу, так і між собою [6]. Цікаво відзначити, що недавно було виявлено значне збільшення числа інфільтруючих моноцитів в острівцях Лангерганса хворих на ЦД 2-го типу в порівнянні зі здоровими особами [7]. Проведені нами дослідження також підтверджують, що клітини природного імунітету грають важливу роль в патогенезі ЦД 2-го типу і ожирінні.

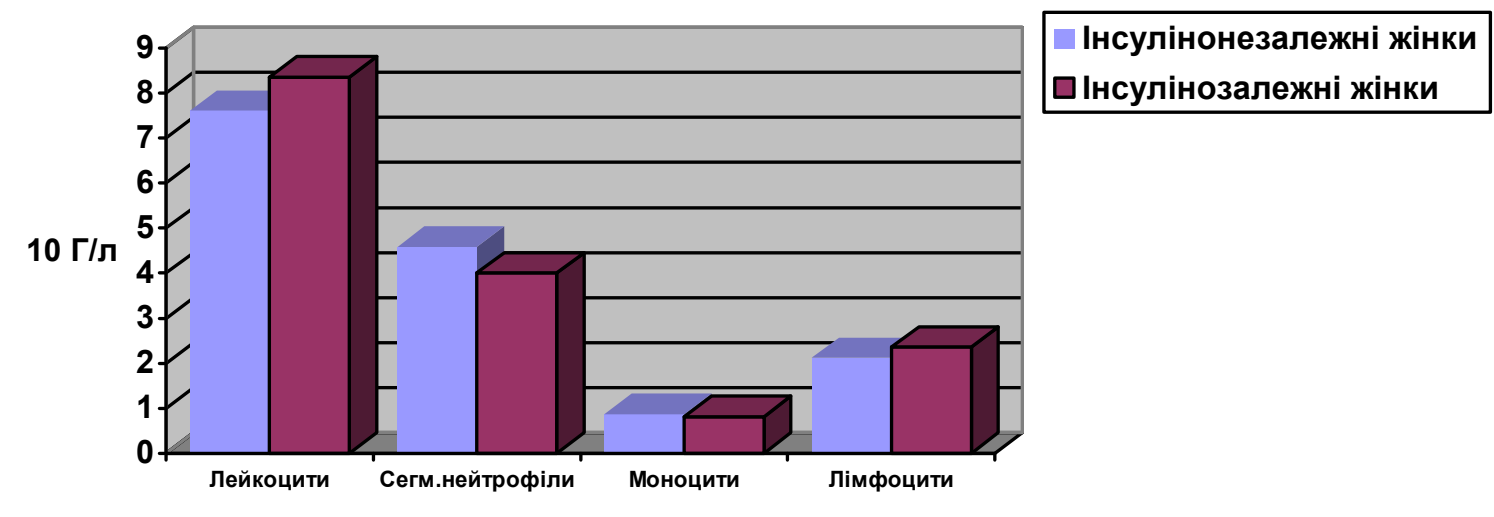

Рисунок 2. Загальна кількість лейкоцитів, абсолютне число нейтрофілів, моноцитів і лімфоцитів в ПК у хворих інсулінозалежних жінок з ожирінням і у хворих на ЦД 2-го типу інсулінонезалежних паціснтів

Згідно 3 отриманими нами даними, підвищення числа лейкоцитів у хворих 3 ЦД 2-го типу багато в чому обумовлено наявністю ожиріння, особливо вираженого у жінок. Разом $з$ тим, воно служить підтвердженням існуючої гіпотези, що ЦД 2-го типу є запальним захворюванням, так як нейтрофільоз i моноцитоз $є$ маркерами хронічного запалення низької інтенсивності. У більшості жінок з вперше виявленим ЦД 2-го типу і нормальними показниками величини маси тіла (IMT $<25$ кг / м2) $є$ тільки незначне і статистично недостовірне підвищення абсолютної кількості CD4 + i CD8 + Т-клітин, що підтверджується публікаціями інших авторів, проведених досліджень на загальній популяції без урахування статі хворих [5]. У той же час, у жінок, які хворіють на ЦД 2-го типу, 3 обтяженим ожирінням були виявлені більш виражені статистично достовірні зміни абсолютної кількості різних субпопуляцій Т-лімфоцитів в ПК порівняно 3 такими у групі здорових жінок з ожирінням, тобто більш висока абсолютна кількість CD3 + Т-клітин (в середньому на $33,3 \%, \mathrm{p}<0,05)$, CD4 + Т-клітин (в середньому на $46 \%$, p < 0,05) і CD8 + Т-клітин (в середньому на 40,5\%, p <0,05) (Рис.3). Зазначимо, що статистично достовірним було зростання CD3 + (на $16,8 \%), \mathrm{CD} 4$ + (на 21\%), CD8 + Т-клітин (на 30\%) у інсулінозалежних жінок з ожирінням відносно інсу- лінонезалежних пацієнтів. Нами було відмічено незначне зростання CD20+-лімфоцитів у всіх дослідних групах, проте воно виявилось статистично недостовірним $(\mathrm{p}>0,05)$. У більшості хворих на ЦД 2-го типу 3 ожирінням відзначалося статистично достовірне підвищення абсолютної кількості природних клітинкілерів (CD56 + клітини) в ПК, що підтверджується і іншими авторами, які виявили підвищення їх цитотоксичної функції [8]. (Рис.4).

Обговорення результатів. Кількість наявних публікацій інших авторів, що стосуються питання вмісту лейкоцитів ПК у хворих на ЦД 2-го типу, невелика i неоднозначна, особливо 3 урахуванням статі хворих і ступеня ожиріння. Відомо, що американські вчені протягом двадцяти років проводили дослідження, що включало 8352 пацієнтів, з яких у 878 чоловік був діагностований ЦД 2-го типу. У групі учасників, у яких розвинувся ЦД 2-го типу, відмічався достовірний $(\mathrm{p}<0,001)$ лейкоцитоз, в порівнянні 3 групою осіб, у яких це захворювання не розвинулося. На думку авторів програми, отримані дані підтверджують гіпотезу про те, що запалення є одним з важливих факторів етіології та патогенезу ЦД 2-го типу [9]. 
A

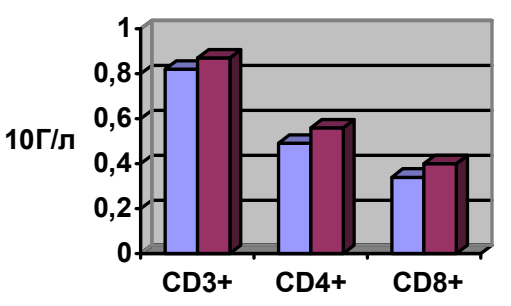

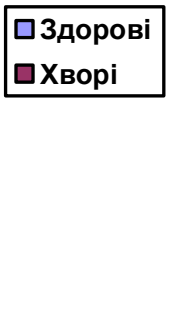

Б

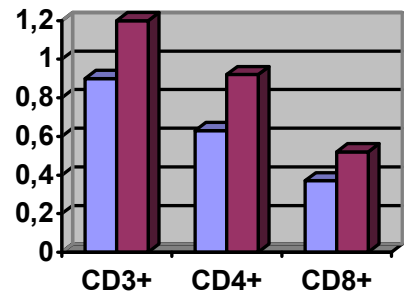

$\square$ Здорові

$\square$ Хворі

Рисунок 3. Абсолютна кількість CD3 + -, CD4 + - i CD8 + Т-лімфоцитів в ПК: А) у здорових худих жінок і худих жінок, хворих на ЦД 2-го типу; Б) у повних здорових жінок і жінок, хворих на ЦД 2-го типу 3 ожирінням
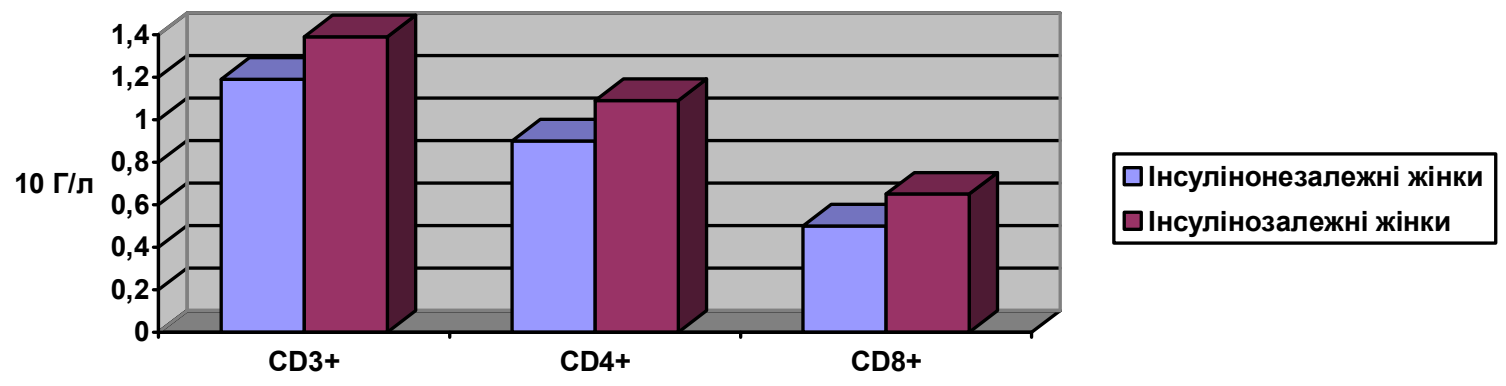

Рисунок 4. Абсолютна кількість CD3 + -, CD4 + - і CD8 + T-лімфоцитів в ПК у хворих інсулінонезалежних жінок з ожирінням і у хворих на ЩД 2-го типу інсулінозалежних паціснтів

Також було виявлено, що у хворих жінок на ЦД 2-го типу лейкоцитоз був більш вираженим ніж, у чоловіків з ЏД 2-го типу. Наведені вище дані підтверджують наші результати. Дослідження показують, що лейкоцитоз у хворих жінок з ЦД 2-го типу, як у худих, так і у повних, обумовлений головним чином збільшенням абсолютних чисел нейтрофілів і моноцитів. Отже, отримані дані підтверджують, що ожиріння відіграє особливу роль в патогенезі і природному перебігу ЦД 2-го типу, що опосередковується різними цитокінами, які секретуються моноцитами ЖТ. Особливість лейкоцитарного складу ПК у жінок, хворих на ЦД 2-го типу з ожирінням пояснюється, тим, що у жінок, порівняно з чоловіками, відзначається більш висока продукція прозапальних цитокінів i, перш за все, адипокінів - лептину та адипонектину [9]. Тому можна вважати, що досліджувана зміна лейкоцитарного складу ПК у хворих на ЦД 2-го типу $\epsilon$ наслідком синергізму самого захворювання і ожиріння. Важливим виявилося дослідження фармакотерапії жінок, хворих на ЦД 2-го типу з ожирінням. Згідно з нашими даними інсулінозалежні жінки мають більш високу імунну реакцію організму за рахунок підвищення лімфоцитів. Цікаво, що при використанні інсуліну в лікуванні ЦД 2-го типу знизилась кількість нейтрофілів і моноцитів, що говорить про зменшення запальної реакції організму в інсулінозалежних пацієнтів. Це надзвичайно важливе питання вимагає подальшого вивчення.

Висновки. У жінок, хворих на ЦД 2-го типу 3 ожирінням, є більш виражені порушення лейкоци- тарного складу ПК і специфічного клітинного імунітету порівняно 3 жінками, хворими на ЦД 2-го типу без ожиріння, що пояснює наявність у них більш вираженого хронічного запалення і причину більш тяжкого перебігу ЦД 2-го типу при ожирінні. Проте використання інсулінотерапії знижуе запальний характер поєднаних захворювань (ШД 2-го типу і ожиріння). Отримані дані дають підставу припускати, що ефективність використання інсуліну обумовлює більш високу протизапальну дію, ніж вживання пероральних цукрознижувальних засобів.

\section{References:}

1. Felicia WP, Jeffrey R, Millman MG. et al. Generation of functional human pancreatic $\beta$ cells in vitro. Cell. 2014; 159(2):428-439.

2. Marchetti P. Islet inflammation in type 2 diabetes. Diabetologia. 2016; 59(4):668-672.

3. Zak KP, Tronko MD, Popova VV, Butenko AK. Saharnyiy diabet. Immunitet. Tsitokinyi. K.: Kniga-plyus, 2015. P.488.

4. Rebrov O. Statystical analysis of medical results. Application of package program STATISTICA. M.: Medyasfera, 2002. P.312.

5. Zak KP. Rol neytrofilnyih leykotsitov v patogeneze saharnogo diabeta 1-go tipa u cheloveka (analiticheskiy obzor s vklyucheniem sobstvennyih dannyih). MIzhnarodniy endokrinologIchniy zhurnal. 2016; 2(74):130-139.

6. Richard C, Wadowski M, Goruk S. Individuals with obesity and type 2 diabetes have additional immune dis- 
function compared with obese individuals who are metabolically healthy. BMJ Open Diab. Res. Care. 2017; 5:19.

7. Donath MY. Multiple benefits of targeting inflammation in the treatment of type 2 diabetes. Diabetologia. 2016; 59(4):679-682.

8. Cildir G, Akincilar SC, Tergaonkar V. Chronic adipose tissue inflammation: all immune cells on the stage. Trends Mol. Med. 2013; 19(8):487-500.

9. Cameron JL, Jain R, Rais M. et al. Perpetuating effects of androgen deficiency on insulin-resistance. Int. J. Obes. 2016; 40(12):1856-1863.

\section{УДК 616-002-008.953-092}

\section{СОСТАВ ЛЕЙКОЦИТОВ ПЕРИФЕРИЧЕСКОЙ КРОВИ: ИММУННЫЕ СВОЙСТВА ЛИМФО- ЦИТОВ ЖЕНЩИН С ОЖИРЕНИЕМ, БОЛЬНЫХ ИНСУЛИНОЗАВИСИМЫМ (НЕЗАВИСИМЫМ) САХАРНЫМ ДИАБЕТОМ ВТОРОГО ТИПА}

Р.О. Сабадышин, А.П. Мялюк, А.В. Штримайтис, А.В. Садовник

Коммунальное учреждение высшего образования «Ровенская медицинская академия» Ровенского областного совета, кафедра

химико-фармачевтических дисциилин,

2. Ровно, Украина,

ORCID ID: 0000-0002-9754-8667,

ORCID ID: 0000-0002-5090-6607,

ORCID ID: 0000-0002-1305-2251,

ORCID ID: 0000-0001-7391-2316,

e-mail: oksankamp@ukr.net

Резюме. На нашей планете каждую двадцать первую секунду появляется новый пациент, страдающий сахарным диабетом. Основную часть этих пациентов составляют больные сахарным диабетом 2 типа. Число лиц с данным диагнозом, которые нуждаются в лечении инсулином, неуклонно растет, и уже давно превысило количество больных сахарным диабетом типа 1. В настоящее время около $30 \%$ всех больных сахарным диабетом 2 типа получают инсулин. Продолжительность периода от дебюта заболевания до начала инсулинотерапии сильно варьирует и зависит от ряда факторов. Например, снижение функциональных возможностей и развитие относительной инсулинопении или потребность в инсулине может быть спровоцирована инсулинорезистентностью, в результате присоединения интеркуррентных заболеваний, беременности, ожирения и т. д.

Обследовано 30 женщин с СД 2-го типа в возрасте от 30 до 50 лет, которые были разделены на две группы: первая - с нормальной массой тела и вторая - с ожирением. Больных женщин с ожирением разделили на две группы, которые являются инсулинозависимыми (независимыми). Контрольная группа составляла 30 здоровых женщин такого же возраста, которые были также разделены на две группы: с нормальным ИМТ (<25 кг / м2) и с ИМТ> 29,9 кг/м2. Установлено, что при ожирении во всех группах наблюдается статистически достоверный лейкоцитоз за счет моноцитоза и нейтрофилеза. Согласно нашим исследованиям, инсулинозависимые женщины имели более высокую иммунную реакцию организма за счет повышения лимфоцитов. При использовании инсулина в лечении СД 2-го типа снизилось количество нейтрофилов и моноцитов, что говорит об уменьшении воспалительной реакции организма в инсулинозависимых пациентов. По результатам исследования эффективность использования инсулина обусловливает более высокое противовоспалительное действие, чем употребление пероральных сахароснижающих средств.

Ключевые слова: лейкоциты, сахарный диабет второго типа, ожирение.

\section{UDC 616-002-008.953-092 COMPOSITION OF PERIPHERAL BLOOD LEUKOCYTES: IMMUNE SYSTEM OF LYM- PHOCYTES IN WOMEN WITH OBESITY, DIA- BETES MELLITUS TYPE 2 PROVIDED WITH INSULIN-DEPENDENT AND NON- INSULIN- DEPENDENT THERAPY}

\author{
R.O. Sabadyshyn, O.P. Myalyuk. O.V. Shtrimaitis,
} O.V. Sadovnik

Municipal Institution of Higher Education «Rivne
Medical Academy» Rivne Regional Council, Rivne, Ukraine,

ORCID ID: 0000-0002-9754-8667,

ORCID ID: 0000-0002-5090-6607,

ORCID ID: 0000-0002-1305-2251,

ORCID ID: 0000-0001-7391-2316,

e-mail:oksankamp@ukr.net

Abstract. Meager and ambivalent results about the role of the immune system in the pathogenesis of diabetes mellitus type II with obesity. There is a view that performances of some indicators of natural and adaptive immunity in patients with diabetes mellitus type II with obesity are due not only to diabetes, but also to the combination of obesity. It has now been discovered that adipose tissue is a powerful secretory organ that produces adipokines (leptin, adiponectin, etc.) They play a key role in various immune responses. However, it is known that the level of major adipokines regulating adipose tissue in peripheral blood of a person is determined taking into account sexual dimorphism, higher concentration among women than among men. Therefore, objective in the work was to know how change white blood cell count and immune properties of blood lymphocytes in insulindependent and non-insulin-dependent obese women with diabetes mellitus type II.

Materials and methods of research. The 30 women with diabetes mellitus type II aged between 30 and 50 years were examined, which were divided into two groups: the first - with normal body weight (body mass index (BMI) $<25 \mathrm{~kg} / \mathrm{m} 2$ ) and with obesity (BMI $>30 \mathrm{~kg} / \mathrm{m} 2$ ). In addition, obese women have been di- 
vided into two subgroups of patients who are insulindependent and non-insulin-dependent. Consequently, the control group consisted of 30 relatively healthy women, same age, who were also divided into two groups: with normal BMI $(<25 \mathrm{~kg} / \mathrm{m} 2)$ and with BMI $>29.9 \mathrm{~kg} / \mathrm{m} 2$. Obesity was diagnosed by determining BMI. Total number of leukocytes was counted using hematological analyzer in the peripheral blood. Leucogram was studied in smears of peripheral blood for 200 cells (RomanowskyGiemsa stain). The lymphocyte content was determined by laser flow cytometry system. Mononuclear cells were isolated from heparinized blood by differential centrifugation.

Results of the research and their discussion. We have found statistically significant leukocytosis in all groups through monocytosis and neutrophilosis in obese women. According to our data, insulin-dependent women had a higher immune response by increasing lymphocytes. By using insulin, the number of neutrophils and monocytes decreased, said that there had been a decrease in the inflammatory response of the body to insulindependent patients.

Conclusions. There are more severe violations of the leukocyte composition peripheral blood and lymphocytic immunity in women with diabetes mellitus type II and obesity compared with women without obesity. That explains the presence of more pronounced chronic inflammation and the reason for the more severe course of diabetes mellitus type II and obesity. However, the use of insulin therapy reduces the inflammatory of combined diseases (diabetes mellitus type II and obesity). Data suggest, however, that the effectiveness of using insulin causes a higher anti-inflammatory effect than the use of oral hypoglycemic drugs. obesity.

Keywords: leukocytes, diabetes mellitus type II,

Стаття надійшла в редакцію 26.04.2019 р. 